\title{
Malaria parasite resistance vicious cycle
}

\author{
Ciclo vicioso da resistência do parasito da malária
}

Ciclo vicioso de resistencia al parásito de la malaria

Valdicley Vieira Vale ${ }^{1,2}$, Dayse Lúcia do Nascimento Brandão ${ }^{1,2}$, Milena Cristina Martins da Silva ${ }^{1}$, Denise Bueno ${ }^{3}$, Michael Dean Green ${ }^{4}$, Sandro Percário ${ }^{1}$, Maria Fani Dolabela ${ }^{1 *}$.

\begin{abstract}
Objective: This paper analyzes the "vicious" cycle of malaria treatment as a consequence of restricted access to anti-malarial drugs. Literature review: Lack of public health policies in affected countries limits access to medicines. This leads patients to acquire drugs in "parallel" markets under the risk of quality deviations or falsified products. The use of these products can aggravate the disease, lead to death, and contribute to parasite resistance to drugs. There are reports of Plasmodium strains resistant to different antimalarial drugs, this creates the need to look for new therapeutic alternatives. These new drugs begin to be counterfeit or people use low quality drugs, selecting resistant strains again, making necessary further research to identify other therapeutic possibilities, restarting this vicious cycle. Final considerations: Therefore, it is important to create conditions for using good quality medicines supervised by health professionals, and ensure research of new alternatives, evaluating their activity on the parasite or the disease.
\end{abstract}

Key words: Malaria, Resistance, Cycle.

\section{RESUMO}

Objetivo: Este artigo analisa o ciclo "vicioso" do tratamento da malária como consequência do acesso restrito a medicamentos antimaláricos. Revisão Bibliográfica: A falta de políticas públicas de saúde nos países afetados limita 0 acesso à medicamentos, isso leva o paciente a adquirir medicamentos em mercados "paralelos" sob o risco de desvios de qualidade ou produtos falsificados. O uso desses produtos pode agravar a doença, levar à morte e contribuir para a resistência do parasita aos fármacos. Já existem relatos de isolados de Plasmodium resistentes a diferentes fármacos antimalárico, isso cria a necessidade de buscar novas alternativas terapêuticas. Estes novos fármacos começam a ser falsificados ou as pessoas utilizam medicamentos de baixa qualidade, novamente seleciona-se cepas resistentes, tornando necessário novas pesquisas que visem identificar outras possibilidades terapêuticas, reiniciando esse ciclo vicioso. Considerações finais: Portanto, é importante criar condições para o uso de medicamentos de boa qualidade, supervisionados por profissionais de saúde e garantir a pesquisa de novas alternativas, avaliando sua atividade no parasita ou na doença.

Palavras-Chave: Malária, Resistência, Ciclo.

\footnotetext{
1 Universidade Federal do Pará (UFPA), Belém-PA. *E-mail: fanidolabela20@gmail.com

2 Universidade Federal de Minas Gerais, Belo Horizonte, MG.

3 Universidade Federal do Rio Grande do Sul (UFRGS), Porto Alegre-RS.

4 US Centers for Disease Control and Prevention (CDC), Atlanta-GA, USA.
}

This study was financed in part by the Coordenação de Aperfeiçoamento de Pessoal de Nível Superior - Brasil (CAPES) - Finance Code 001. 


\section{RESUMEN}

Objective: Este artículo analiza el ciclo "vicioso" del tratamiento de la malaria como consecuencia del acceso restringido a los medicamentos antipalúdicos. Review of literature: La falta de políticas de salud pública en los países afectados limita el acceso a los medicamentos, lo que lleva al paciente a comprar medicamentos en mercados "paralelos" a riesgo de desviaciones de calidad o productos falsificados. El uso de estos productos puede agravar la enfermedad, provocar la muerte y contribuir a la resistencia del parásito a las drogas. Ya hay informes de diferentes aislados de Plasmodium resistentes a los medicamentos. antipalúdicas, esto crea la necesidad de buscar nuevas alternativas terapéuticas. Estas nuevas drogas comienzan a ser falsificados o las personas usan medicamentos de baja calidad, nuevamente seleccionan cepas resistentes, realizan más investigaciones para identificar otras posibilidades terapéuticas, reinicie este círculo vicioso. Consideraciones finales: Por lo tanto, es importante crear condiciones para el uso de medicamentos de buena calidad supervisados por profesionales de la salud y garantizar la búsqueda de nuevas alternativas, evaluando su actividad en el parásito o la enfermedad.

Palabras clave: Malaria, Resistencia, Ciclo.

\section{INTRODUCTION}

Malaria is a disease caused by a parasite of the genus Plasmodium transmitted to humans through the bites of infected mosquitoes. People who have the disease usually have a high fever and shaking chills. Globally, despite worldwide efforts to restrain the disease, an estimated 3.2 billion people are still at risk of being infected with malaria and developing the disease, and 1.2 billion are at high risk. Per the latest estimates, 216 million cases of malaria occurred globally in 2017 an increase of 5 million cases over the previous year, and the disease led to 435.000 deaths. The burden is heaviest in the African Region, where an estimated $90 \%$ of all malaria deaths occur (WHO, 2019).

Most deaths (78\%) occurs in children under 5 years, particularly in Sub-Saharan African where one death by malaria is registered every 2 minutes. Indeed, malaria occurs mainly in developing countries; in which this disease was neglected for many years as a result of the lack of governmental well-structured drug policies for malaria treatment. Consequently, the population has no guaranteed access to medicines, or at least, quality drugs which hinders therapeutic success and expands the number of victims of the disease (WHO, 2019; GETHING PW, et al., 2012).

The use of low quality or counterfeit drugs may contribute to select drug resistant Plasmodium strains, so changing therapeutic regimen to treat the patient becomes necessary. If not treated correctly, the parasite may acquire resistance to new drugs. In this scenario, multidrug resistant Plasmodium isolates can be obtained and the search for new therapeutic alternatives is essential (NOEDL H, et al., 2009).

The access to good quality medicines including malaria drugs is a human right and strategies to guarantee this should be taken. In Brazil, for example, since the approval of the Federal Constitution, health is a universal right guaranteed by the State. Through this new principle, the National Drug Policy and the Pharmaceutical Assistance Policy consider the purchase and distribution of antimalarial drugs as a strategic component (HUNT P e KHOSLA R, 2008; BRASIL MS, 1998; BRASIL MS, 2004). In this review, we analyze the "vicious" cycle of malaria treatment as consequence of the lack of access to anti-malarial drugs, the factors that interfere in the treatment and the main strategies that should be adopted to ensure therapy success.

\section{LITERATURE REVIEW}

\section{The lack of access to anti-malarial drugs}

Access to drugs is highly uneven. Developed countries spend, on average, 100 times more per capita with drugs than developing countries. The World Health Organization (WHO) estimates that $15 \%$ of the world population consumes more than $90 \%$ of the pharmaceutical production. It is noteworthy that malaria occurs 
mainly in developing countries where access to medicines in general is very limited (WHO, 2004; UNDP, 2000; HUNT P e KHOSLA R, 2008; GETHING PW, et al., 2012).

In this context, accessibility to medicines must be understood in four dimensions. First, medicines must be accessible in all parts of the country, including remote areas more susceptible to malaria. This involves the establishment of an adequate logistic distribution. Inadequate antimalarial drug distribution and storage (high temperatures and humidity) can reduce product quality (HUNT P e KHOSLA R, 2008; NOGUEIRA FHA, et al., 2011).

Second, drugs should be affordable for everyone, including people living below the poverty line. For this reason, it is necessary to have a governmental drug funding or public health policy that enables free access to antimalarials (HUNT P e KHOSLA R, 2008).

Third, universal access to antimalarial drugs should not allow discrimination based on any parameter such as gender, ethnicity, or socioeconomic status (HUNT P e KHOSLA R, 2008). Finally, the fourth and last important factor is access to reliable information and free medicinal products to enable users to make informed decisions to safely use the medicines. High quality health or medicinal information can improve malaria treatment adherence, reduce dropout rate, and prevent parasitic resistance. Dropout, inadequacy, or deprivation of treatment generates numerous avoidable suffering, such as high rates of morbidity, fear, loss of dignity, absence from work or school activities, and increased death rates (HUNT P e KHOSLA R, 2008).

To improve access to antimalarial medicines, it is necessary to consolidate State policies with established sustained funding criteria, and affordable and adequate drug distribution system as well. It is noteworthy that governments need to enlarge their lending capacity, efficient use of resources, and market regulation (WHO, 2004; BOING AC, et al., 2013).

\section{Use of counterfeit or low-quality drugs and its consequences}

In Belem (PA, Brazil), Brazilians miners working in neighboring countries often return to Brazil with malaria. They intend to use the Brazilian health system to treat the disease, then return to mining. The reason for that relies on the cost of the medication at the mining site, where malaria medicines are paid in gold's weight. Therefore, miners end up taking only 1 or 2 dosages at the mining site, returning to Brazil to complete malaria treatment. Once they get better, they return to the gold mine (RECHT J, et al., 2017).

In 2003, a survey of antimalarial drug quality was conducted by using a stratified random sampling method in the Democratic Republic of Laos (Laos). In this study the availability and quality of antimalarials in the private sector was evaluated, and $84 \%$ of artesunate samples showed forgery signs. In 2012 , this survey was repeated to assess changes over time. The availability of artesunate monotherapy sales points reduced significantly $(2003=22.9 \% ; 2012=4.8 \% ; p<0.0001)$, and all samples contained the correct active ingredient. However, although none of the samples purchased had proven to be forgery, in $25.4 \%$ of the samples, the active ingredient content was lower than recommended by the pharmacopeia $(<90 \%$ of the reported dose on the label). This result suggested that poor transport and/or storage conditions might have interfered with active ingredient contents. According to the authors, the quality of combination therapies based on artemisinin (CTAs) and other antimalarial drugs must be monitored because the exposure to counterfeit drugs or quality deviation can have devastating consequences on public health (TABERNERO P, et al., 2015).

A similar situation was reported in Southeast Asia, where a high percentage of antimalarial drugs are probably counterfeits. The purchase of drugs out of legalized health establishments exposes the user to the risk of acquiring low quality or fake drugs (DONDORP AM, et al., 2004).

Most cases of Plasmodium resistance to drugs occurred in Cambodia and nearby regions. This may be related to adoption of monotherapy; treatment regimen failure due to use of the remaining doses in relapse or reinfection by people who live in difficult to access areas; and inefficient government policies that assure the consumption of quality medicines, allied to the fact that the government cannot act in territories controlled by rebel groups (ROBERTS L, 2006). 
Another survey conducted in seven African countries, showed that $20 \%$ to $90 \%$ of antimalarial drugs had quality deviation. Other studies, conducted in East Africa, demonstrated lack of quality and fake medicines containing artemisinin derivatives and mefloquina (SURENDRAN A, 2004; ABDI YA, et al., 1995; KELESIDIS T, et al., 2007; TAYLOR RB, et al., 2001; NEWTON P, et al., 2001; GREEN MD, et al., 2000; ROZENDAAL J, 2001).

Programs that aim to combat the selling of counterfeit drugs are extremely urgent. Society needs to know about the use of counterfeit antimalarial consequences. Studies to assess the impact of such programs on the improvement of antimalarial drugs quality available in the market has not been carried out so far (TORRES C, 2010; TABERNERO P, et al., 2015).

The use of counterfeit drugs with active ingredients content lower than the recommended level can lead to treatment failure, clinical worsening and death, increases both the cost of treatment due to hospitalization of patients and $P$. falciparum resistance rates (KARUNAMOORTHI K, 2014; YEUNG S, et al., 2015).

In 2008, $P$. falciparum resistance to artemisinin monotherapy was observed. This resistance emergence is due to selective drug pressure, the use of monotherapy or sub-therapeutic concentrations (NOEDL H, et al., 2009; MIOTTO O, et al., 2013).

Several factors may contribute to plasma drug concentration at the sub-therapeutic range: incorrectly prescribed or dispensed dose; lack of treatment adherence; and low product quality or forgery. Therefore, such factors create a "vicious" cycle in malaria treatment. The use of low quality or counterfeit drugs (due to lack of quality in manufacturing process, transportation or storage) results in increased disease severity, mortality rates, and resistant strains of $P$. falciparum (YEUNG S, et al., 2015) (Figure 1).

Figure 1 - Cycle of parasite resistance.

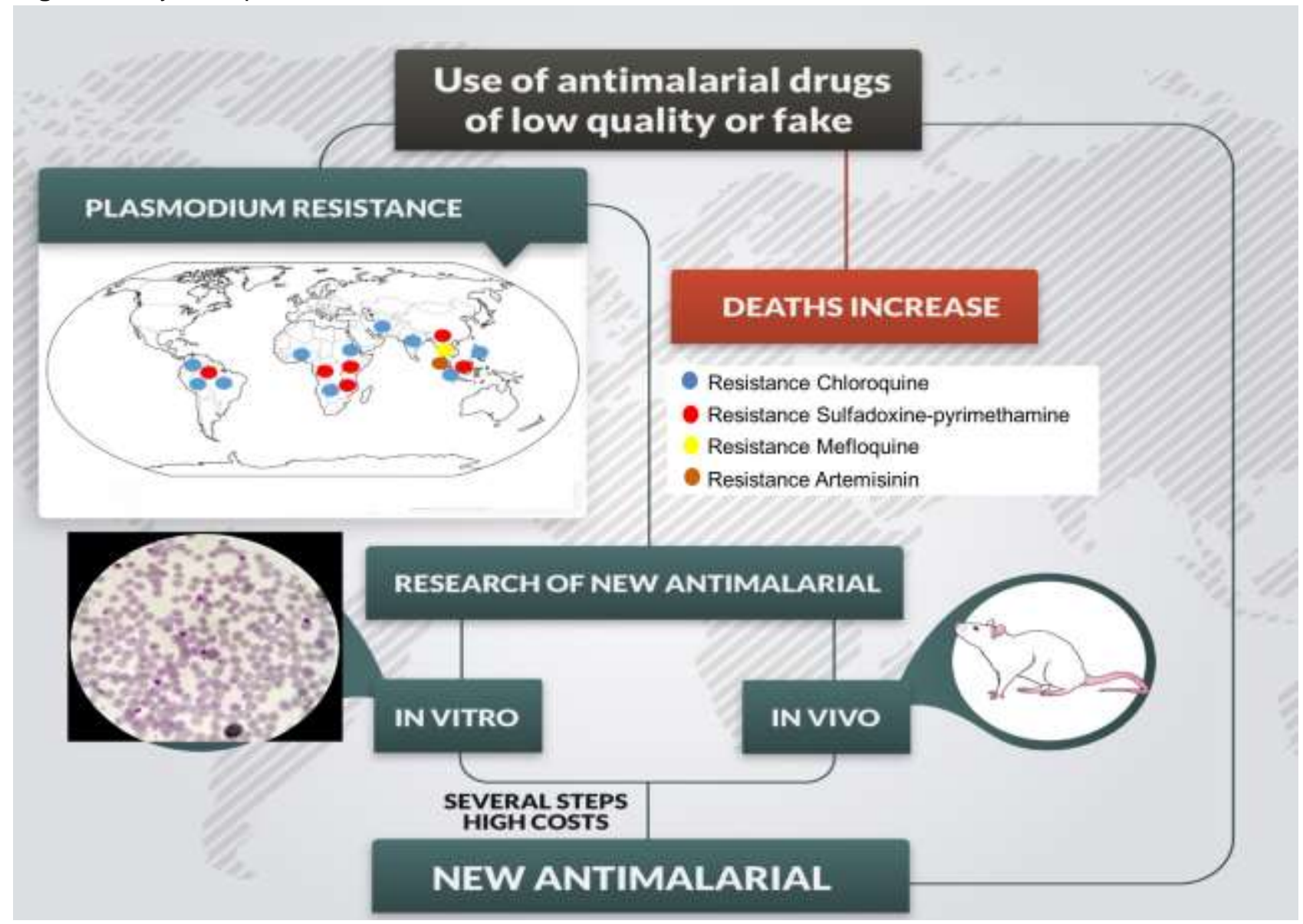

Fonte: Vale VV, et al., 2019. 
Brazil is a continental size country, where the transport of drugs released by the government is centralized and can be done by trucks or boats, with high temperatures and humidity levels. After transportation, the medicine is distributed to health facilities that usually have no suitable storage places. Also, the user often receives the medicine without guidance on how to use it (NOGUEIRA FHA, et al., 2011).

Hence, access to drug needs to be planned at a local logic level and supported by the local health team. Among other factors, it is imperative to work towards the combat of counterfeit antimalarial drugs (NEWTON PN, et al., 2006).

Nevertheless, the prevalence of fake drugs varies from country to country. Highest percentages are found in some countries in Africa, Latin America and Southeast Asia. Experts estimate that up to $10 \%$ of medicines used worldwide are counterfeits (COCKBURN R, et al., 2005).

According to the FDA, just 5 cases of fake drugs/year were reported by the year 2000 in US. However, since 2001 the average increased to 20 per year. Most these cases involved products sold thru global network (Internet) or black market. Notwithstanding, just few cases were found in official drugs distribution system in this country (SURENDRAN A, 2004).

Some countries where the disease is endemic have no completely structured public health systems to provide pharmacy services for the improvement of transport, storage and dispensing conditions. It is recommended to dispense the drug in its original packaging, along with the dosage regimen specified in local language. Furthermore, the presence of a pharmacist to give proper orientation and monitor the treatment can inhibit and detain drug counterfeiting (NOGUEIRA FHA, et al., 2011; TABERNERO P, et al., 2015).

Another important situation to consider involves drugs originally of good quality, but if it is not prescribed in appropriate dose, or if there is no adherence to treatment, drug response may be compromised due to plasma concentrations at a sub-therapeutic range, favoring the selection of resistant parasite strains (MOCKENHAUPT FP, et al., 2000).

It is known that quinine - the first antimalarial drug introduced in 1632 - presented the first resistance case recorded just 278 years after its introduction; the time elapsed between the introduction of chloroquine as antimalarial and emergence of resistance was 12 years (1945 and 1957, respectively); mefloquine was introduced in 1977 and the first resistance case was reported in 1982, therefore just five years later; the emergence of resistant strains to proguanil took only one year. Similarly, resistant $P$. falciparum strains were isolated in the same year of sulfadoxine - pyrimethamine and atovaquone introduction. The latter drugs to enter in this market, artemisinin and its derivatives, have also resistance cases reported (PETERS W, 1987; WERNSDORFER WH e PAYNE D, 1991; WONGARICHANALAI C, et al., 2002; ASHLEY EA, et al., 2014).

In the case of malaria treatment, some measures should be adopted. The use of monotherapy causes a selective pressure on $P$. falciparum, favoring the development of resistance. Therefore, monotherapy is not recommended. The dispensing of drugs, whenever possible, should be performed by pharmacists. Measures to prevent non-compliance of drug treatment should be implemented; a strategy could be the daily supervised dose program (CUNICO W, et al., 2008).

Should supervised administration be adopted, it is necessary to have extended-release drugs to administer a single dose per day. The health professional can go daily to the patient's home, do a previous interview to analyze the patient condition, and then administrate the drug. This measure can ensure not only adherence, but also the detection of adverse or toxic reactions, and evaluate the therapeutic response as well (PIMENTEL LF, et al., 2007).

In such context, the search for new antimalarial drugs is extremely important, as well as to promote their rational use. WHO suggests properly drug prescription, pharmaceutical form, dose and duration of treatment; drug should be available in a timely manner, at an affordable price, and always responds to the required quality criteria; dispensed under appropriate conditions, with the necessary guidance and accountability, and finally meets the therapeutic regimen prescribed (WHO, 1987). Noncompliance to these requirements may lead to resistance emergence of new drugs, making necessary further studies of new drug development (Figure 2). 
Figure 2 - Vicious cycle of antimalarial therapy

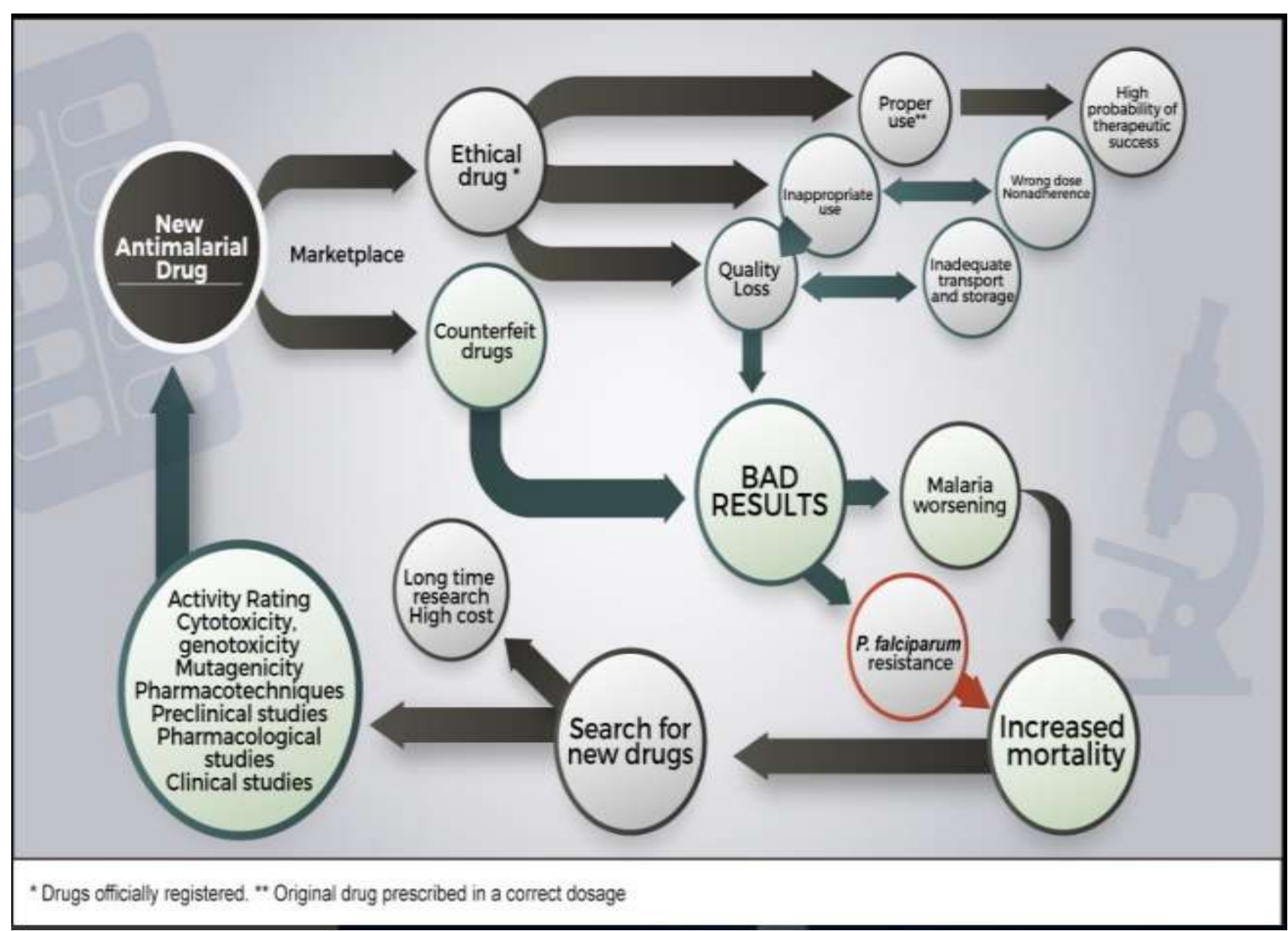

Fonte: Vale VV, et al., 2019.

Due to the high cost of searching for new drugs, pharmaceutical industry has adopted the following strategies: adding of small structural changes to existing drugs, and development of new medicines containing the same active ingredients (WU T, et al., 2011).

The development of new pharmaceutical forms has been focused on liposomal forms as nanoparticles. These technologies generally increase the cost of the drug and reduces access to them. It is noteworthy that malaria occurs mainly in developing countries, thus it is necessary to evaluate the viability of this type of strategy (PIMENTEL LF, et al., 2007).

Seeking alternative therapies (new drugs) is indispensable, but the research requires a long period of clinical studies, and high financial investment. Besides, should these new drugs come to market, issues related to forgery, transport, disqualified storage, inadequate dispensing and inappropriate use remain, and resistance to the new drug may arise rapidly (NOGUEIRA FHA, et al.,2011).

The searching for new antimalarial drugs is extremely important. To find new therapeutic alternatives, this group has been extensively evaluating the activity of traditional medicinal plants of the Amazon. Among the several species studied by this group, some examples are listed:

The ethanolic extract and fractions obtained from bulbs of Eleutherine plicata underwent antimalarial activity evaluation against a chloroquine-resistant strain of $P$. falciparum (W2). Both the ethanolic extract $\left(\mathrm{Cl}_{50} 6.57 \pm\right.$ $1.03 \mu \mathrm{g} / \mathrm{mL}$ ) and the dichloromethane fraction $\left(\mathrm{Cl}_{50}=2.87 \pm 0.82 \mu \mathrm{g} / \mathrm{mL}\right.$ ) significantly inhibited parasite development. However, the fractioning of the extract lead to a higher cytotoxic dichloromethane fraction $\left(\mathrm{CC}_{50}\right.$ $19.61 \pm 0.78 \mu \mathrm{g} / \mathrm{Ml})$, with greater genotoxicity. For this reason, the ethanolic extract of E. plicata $(300 \mathrm{mg} / \mathrm{kg})$, 
was used to treat $P$. berghei Anka-infected mice, yelding a $60 \%$ reduction of parasitemia. Furthermore, treated animals did not developed cerebral malaria, no significant pulmonary disease was observed, and there was no death of any animal (ROCHA-GALUCIO NC, 2014).

Another plant evaluated was Aspidosperma nitidum, which had its extract and alkaloid-rich fraction subjected to in vitro antimalarial activity evaluation against $P$. falciparum (W2), and the fractionation obtained per acid-base partition proved to be beneficial, as the extract showed lower antiplasmodial activity $\left(\mathrm{IC}_{50}=3.60\right.$ $\pm 0.37 \mu \mathrm{g} / \mathrm{mL})$ than the alkaloid-rich fraction $\left(\mathrm{IC}_{50}=2.32 \pm 0.19 \mu \mathrm{g} / \mathrm{mL}\right)$. Another advantage of the fractionation was the fact that the alkaloid-rich fraction proved to be more selective $\left(\mathrm{CC}_{50}=346.73 \pm 14.17 \mu \mathrm{g} / \mathrm{mL}\right.$; IS: 135.49 ) that the extract $\left(\mathrm{CC}_{50}=410.65 \pm 9.84 \mu \mathrm{g} / \mathrm{mL}\right.$; IS: 114.07$)$ on HepG2 cells. In the in vivo test, using $P$. berghei Anka-infected mice, a reduction of parasitemia in animals treated with ethanolic extract of $A$. nitidum or the alkaloid-rich fraction was seen. In addition to the reduction of parasitemia, a significant clinical improvement we noted, i.e., animals showed no symptoms of cerebral malaria and increased length of survival. In summary, A. nitidum proved to display good antiplasmodial activity (MARTINS MT, 2012).

Similar results were noted for Geissospermum vellosii, which ethanolic extract $\left(\mathrm{IC}_{50}=11.13 \pm 3.59 \mu \mathrm{g} / \mathrm{mL}\right)$ and alkaloid fraction $\left(\mathrm{IC}_{50}=2.69 \pm 0.38 \mu \mathrm{g} / \mathrm{mL}\right)$ showed in vitro activity against $P$. falciparum (W2). However, the alkaloid fraction was more cytotoxic $\left(C_{50}=299.63 \pm 21.29 \mu \mathrm{g} / \mathrm{m}\right)$ and less selective $(I S=111.39)$ than the ethanolic extract $\left(C_{50}=517.28 \pm 42.98 \mu \mathrm{g} / \mathrm{mL}\right.$; IS=46.48). Mice infected with $P$. berghei were treated with the ethanolic extract, resulting in significant clinical improvement and increasing of survival time (BRANDÃO DLN, 2012).

Conversely, some popularly used species showed contradictory results, as showed low antiplasmodial activity when only the in vitro activity as accessed. Notwithstanding, when mice infected with $P$. berghei ANKA were treated with those plants, both clinical and oxidative improvement was noted (VALE VV, et al., 2015).

An example is Himatanthus Articulatus. In vitro assays showed no parasitemia reduction for $P$. falciparum. However, tests in mice infected by $P$. berghei, and treated with $H$. Articulatus extract had significant clinical results in deaths during the test period, and the signs of cerebral malaria. These effects may be related to changes in oxidative stress in animals, since the development of cerebral malaria in infections by $P$. berghei needs an increased nitric oxide (NO) concentration (VALE VV, et al., 2015).

Parahancornia fasciculata is another specie widely used in traditional medicine that have no in vitro activity, but significant clinical results were observed in mice infected with $P$. berghei (SILVA AO, 2013). These results make us think that the Amazon plants can be used with two different goals: to act against the parasite or to improve the disease symptoms. Hence, the activity evaluation of these plants should involve an in vitro step in growing strains of $P$. falciparum, and in vivo, associated with clinical and oxidative stress evaluation. Thus, it will be possible to state whether the plant has antiparasitic effect or just reduces the severity of disease (VALE VV, et al., 2015).

\section{FINAL CONSIDERATIONS}

After analysing the cycle of antimalarial drugs (distribution, storage, ensuring people's access and treatment) and the strategies for searching new medicines, it is thought that adoption of national policies for malaria treatment to ensure drugs quality, the implementation of supervised dose programs, carried out with an interview and structured questionnaire for early detection of adverse events and continue the search for new drugs, evaluating antiplasmodial activity (both in vitro and in vivo studies) and on the progression of the disease (clinical and oxidative stress evaluation) are some measures that must be taken to break the vicious cycle of malaria treatment.

\section{ACKNOWLEDGMENTS AND FUNDING STATEMENT}

To Capes by granting scholarships. This study was financed in part by the Coordenação de Aperfeiçoamento de Pessoal de Nível Superior - Brasil (CAPES) - Finance Code 001. 


\section{REFERÊNCIAS}

1. ABDI YA, et al. Quality of chloroquine preparations marketed in Dar es Salaam, Tanzania. Lancet, 1995; 346(8983): 1161.

2. ASHLEY EA, et al. Spread of artemisinin resistance in Plasmodium falciparum malaria. New England Journal of Medicine, 2014; 371(5): 411-423.

3. BOING AC, et al. Acesso a medicamentos no setor público: análise de usuários do Sistema Único. Cad. Saúde Pública, 2013; 29(4): 691-701.

4. BRANDÃO DLN. Portulaca pilosa L. e Geissospermum velosii leavis: estudos botânicos, farmacognóstico, fitoquímico e atividades biológicas Dissertação (Mestrado em Ciênicas Farmacêuticas) - Instituto Ciênicas da Saúde. Universidade Federal do Pará, Belém 2012; 123 p.

5. Brasil, Ministério da Saúde- Resolução № 338 de 06 de maio de 2004 (DOU, Brasília-DF, Brazil, 06 de maio de 2004).

6. Brasil, Ministério da Saúde, Portaria N³.916 de 30 de outubro de 1998 (DOU, Brasília, Brazil, 30 de outubro de 1998).

7. COCKBURN R, et al. The global threat of counterfeit drugs: why industry and governments must communicate the dangers. PLOS Medicine, 2005; 2(4): e100.

8. CUNICO W, et al. Fármacos antimalariais-história e perspectivas. Revista Brasileira de Farmácia, 2008; 89(1): 4955.

9. DONDORP AM, et al. Fake antimalarials in Southeast Asia are a major impediment to malaria control: multinational cross-sectional survey on the prevalence of fake antimalarials. Tropical Medicine \& International Health, 2004; 9(12): 1241-1246.

10. GETHING PW, et al. A long-Neglected World Malaria Map: Plasmodium vivax Endemicity in 2010. PLOS Neglected Tropical Diseases, 2012; 6(6): e1814.

11. GREEN MD, et al. A colorimetric field method to assess the authenticity of drugs sold as the antimalarial artesunate. Journal of Pharmaceutical and Biomedical Analysis, 2000; 24(1): 65-70.

12. HUNT P, KHOSLA R. The Human Right to Medicines. Revista Internacional de Direitos Humanos, 2008; 5(8): 100121.

13. KARUNAMOORTHI $\mathrm{K}$, the counterfeit anti-malarial is a crime against humanity: a systematic review of the scientific evidence. Malar Journal, 2014; 13: 209.

14. KELESIDIS T, et al. Counterfeit or substandard antimicrobial drugs: a review of the scientific evidence. Journal of Antimicrobial Chemotherapy, 2007; 60(2): 214-236.

15. MARTINS MT. Estudo farmacognóstico, fitoquímico e atividades biológicas de Aspidosperma nitidum Benth. Ex Mull. Arg. Dissertação (Mestrado em Ciênicas Farmacêuticas) - Instituto Ciênicas da Saúde. Universidade Federal do Pará, Belém 2012; 123 p.

16. MIOTTO O, et al. Multiple populations of artemisinin resistant Plasmodium falciparum in Cambodia. Nature Genetics, 2013; 45(6): 648-655.

17. MOCKENHAUPT FP, et al. Concentrations of Chloroquine and malaria parasites in blood in Nigerian children. Antimicrobial Agents and Chemotherapy, 2000; 44(4): 835-839.

18. NEWTON P, et al. Fake artesunate in southeast Asia. Lancet, 2001; 357(9271): 1948-1950.

19. NEWTON PN, et al. Counterfeit anti-infective drugs. The Lancet Infectious Diseases, 2006; 6(9): 602-613.

20. NOEDL H, et al. Artemisinin-resistant malaria in Asia. New England Journal of Medicine, 2009; 361(5): $540-541$.

21. NOGUEIRA FHA, et al. Quality of essential drugs in tropical countries: evaluation of antimalarial drugs in the Brazilian Health System. Revista da Sociedade Brasileira de Medicina Tropical, 2011; 44(5): 582-586.

22. PETERS W. Chemotherapy and drug resistance in malaria. London, England: Academic Press, 1987; 786p.

23. PIMENTEL LF, et al. Nanotecnologia farmacêutica aplicada ao tratamento da malária. Revista Brasileira de Ciências Farmacêuticas, 2007; 43(4): 503-514.

24. RECHT J, et al. Malaria in Brazil, Colombia, Peru and Venezuela: current challenges in malaria control and elimination. Malaria Journal, 2017; 16 (273): 1-18.

25. ROBERTS L, Malaria Wars, Science, 2016; 352(6284): 398-405.

26. ROCHA-GALUCIO NC. Estudos fitoquímicos, citotoxicidade e genotoxicidade de Eleutherine plicata Herb. Dissertação (Mestrado em Ciênicas Farmacêuticas) - Instituto Ciênicas da Saúde. Universidade Federal do Pará, Belém, 2014; 95 p.

27. ROZENDAAL J. Fake antimalaria drugs in Cambodia. Lancet, 2001; 357(9259): 890.

28. SURENDRAN A. World agencies try to stem flood of fake drugs. Nature Medicine, 2004; 10(2): 111.

29. TABERNERO P, et al. A Repeat Random Survey of the Prevalence of Falsified and Substandard Antimalarials in the Lao PDR: A Change for the Better. The American Journal of Tropical Medicine and Hygiene, 2015; 92(6): 95-104. 
30. TAYLOR RB, et al. Pharmacopoeial quality of drugs supplied by Nigerian pharmacies. Lancet, 2001; 357(9272): 1933-1936.

31. TORRES C. Counterfeiting goes cinematic in public campaigns. Nature Medicine, 2010; 16: 363.

32. UNDP, Resolution adopted by the General Assembly: United Nations Millennium Declaration (United Nations Development Programme, New York, 2000).

33. WERNSDORFER WH, Payne D. The dynamics of drug resistance in Plasmodium falciparum. Pharmacology \& Therapeutics, $1991 ; 50(1)$ : 95-121.

34. WHO. The rational use of drugs: report of the conference of experts. Nairobi 25-29 november 1985. Geneva: World Health Organization, 1987.

35. WHO. World Malaria Report 2019. Geneva: World Health Organization; 2019.

36. WHO: Estrategia farmacéutica de la OMS: lo esencial son los países, 2004-2007. Geneva: World Health Organization; 2004.

37. WONGARICHANALAI C, et al. Epidemiology of drug-resistant malaria. Lancet, 2002; 2(4): 209-218.

38. WU T, et al. Road towards new antimalarials - overview of the strategies and their chemical progress. Current Medicinal Chemistry, 2011; 18(6): 853-871.

39. YEUNG S, et al. Quality of Antimalarials at the Epicenter of Antimalarial Drug Resistance: Results from an Overt and Mystery Client Survey in Cambodia. The American Journal of Tropical Medicine and Hygiene, 2015; 92(6): 39-50. 